Jurnal Biologi dan Pembelajarannya, Vol 6 No 2, Oktober 2019. Pp: 4-6

e-ISSN: $2406-8659$

\title{
EFEKTIFITAS MODEL PEMBELAJARAN PAIR CHECKS TERHADAP HASIL BELAJAR BIOLOGI SISWA KELAS VIII SMP NEGERI 6 LUBUKLINGGAU
}

\author{
Ivoni Susanti, Nopa Nopianti \\ Pendidikan Biologi, STKIP PGRI Lubuklinggau \\ Lubuklinggau , 31617, Indonesiaa \\ Email: nopachandrai@gmail.com
}

\begin{abstract}
Abstrak
Penelitian ini bertujuan untuk mengetahui Efektifitas model pembelajaran Pair Checks terhadap hasil belajar biologi siswa kelas VIII SMP Negeri 6 Lubuklinggau. Metode penelitian kuatitatif dan menggunakan desain pretest-postest control group design. Pengumpulan data dilakukan dengan teknik tes. Data yang dikumpulkan akan dianalisis dengan menggunakan uji-t pada taraf signifikan $\alpha=0,05$. Berdasarkan hasil analisis menunjukan ada pengaruh model pembelajaran Pair Checks terhadap hasil belajar biologi siswa kelas VIII SMP Negeri 6 Lubuklinggau. Hal ini dapat diketahui dari nilai rata-rata pre-test dan post-test kelas eksperimen adalah 40,20 dan 82,20 . Sedangkan nilai rata-rata pre-test dan post-test kelas kontrol adalah 43,52 dan 61,81 . Hasil tersebut menunjukan ada peningkatan hasil belajar untuk kelas eksperimen sebesar 42,00 sedangkan untuk kelas kontrol sebesar 18,29. Sehingga dapat disimpulkan bahwa model pembelajaran Pair Checks efektif dalam meningkatkan hasil belajar biologi siswa kelas VIII SMP Negeri 6 Lubuklinggau.
\end{abstract}

Kata kunci_Efektifitas, Hasil Belajar, Pair Checks

\section{PENDAHULUAN}

Peranan guru antara lain menguasai dan mengembangkan materi pelajaran, merencanakan dan mempersiapkan pelajaran sehari-hari, mengontrol dan mengevaluasi kegiatan siswa. Guru memiliki peran yang sangat penting dalam pelaksanaan pendidikan demi mencapai tujuan pendidikan yang hendaki,dimana dalam melaksanakan kegiatan pendidikan melalui proses belajar mengajar dengan melibatkan peserta didik atau siswa. Menurut Supriyatna [1], proses pembelajaran yang diterapkan harus membuat siswa aktif dan berani dalam mengeluarkan pendapat, sehingga dapat memberi pengalaman langsung.

Model pembelajaran yang menuntut siswa aktif, mandiri serta dapat melatih siswa bekerjasama dalam sebuah tim dapat dengan menerapkan model pembelajaran Pair Checks. Sesuai dengan yang dikemukakan oleh Suprijono [2], bahwa model pembelajaran Pair Checks adalah model yang menerapkan pembelajaran kooperatif yang menuntut kemandirian dan kemampuan siswa dalam menyelesaikan persoalan yang diberikan. Model pembelajaran siswa yaitu pair check ini juga melatih tanggung jawab sosial siswa, kerja sama, dan kemampuan memberi penilaian. Model pembelajaran sederhana tetapi sangat bermanfaat dikembangkan oleh Frank Lyman dari University of Maryland. Ketika guru menyampaikan pelajaran kepada kelas, para siswa duduk berpasangan dengan timnya masing-masing. Guru memberikan pertanyaan kepada kelas. Siswa diminta untuk memikirkan sebuah jawaban dari mereka sendiri, lalu berpasangan dengan pasangannya untuk mencapai sebuah kesepakatan terhadap jawaban.

\section{METODE PENELITIAN}

Dalam penelitian ini desain penelitian menggunakan dua kelas yaitu kelas eksperimen dan kelas kontrol. Kedua kelas diberikan perlakukan pre-test untuk mengetahui kemampuan awal siswa. Kelas eksperimen menggunakan model pembelajaran Pair Checks dan untuk kelas kontrol menggunakan model pembelajaran konvensional. Setelah penerapan model pembelajaran, kedua kelas diberikan post-test untuk mengetahui kemampuan akhir siswa. Untuk melihat ada tidaknya pengaruh model pembelajaran Pair Checks terhadap hasil belajar siswa kelas VIII SMP Negeri 6 Lubuklinggau.

\section{HASIL DAN PEMBAHASAN}

Hasil penelitian menunjukan adanya perbedaan hasil belajar sebelum dan sesudah penerapan model pembelajaran Pair Checks yang ditunjukan pada tabel 1 dan 2. 
Jurnal Biologi dan Pembelajarannya, Vol 6 No 2, Oktober 2019. Pp: 4-6

e-ISSN: $2406-8659$

Tabel 1. Rekapitulasi Hasil Pre-test

\begin{tabular}{|c|c|c|}
\hline Kelas & Rata-Rata & Simpangan Baku \\
\hline Eksperimen & 40,20 & 13,28 \\
Kontrol & 43,52 & 13,18 \\
\hline
\end{tabular}

Berdasarkan tabel 1 dapat dilihat hasil prê-test antara kelas kontrol dan eksperimen hasil tidak menunjukan adanya perbedaan yang signifikan terhadap hasil belajar siswa.

Tabel 2. Rekapitulasi Hasil Post-test

\begin{tabular}{|c|c|l|c|}
\hline Kelas & Rata-Rata & Simpangan Baku & Ketuntasan \\
\hline Eksperimen & 82,20 & 9,04 & $90,00 \%$ \\
Kontrol & 61,81 & 11,69 & $25,81 \%$ \\
\hline
\end{tabular}

Berdasarkan tabel diatas, menunjukan bahwa nilai rata-rata post-test untuk kelas eksperimen sebesar 82,20 dengan simpangan baku sebesar 9,04. Sedangkan nilai rata-rata post-test untuk kelas kontrol dengan sebesar 61,81 dengan simpangan baku sebesar 11,69. Jika dilihat nilai rata-rata hasil post-test kelas eksperimen dan kelas kontrol terdapat perbedaan nilai sebesar 20,39. Hal ini menunjukkan bahwa kelas yang diterapkan dengan model pembelajaran Pair Checks hasilnya lebih tinggi dari kelas yang diterapkan metode ceramah dan tanya jawab.

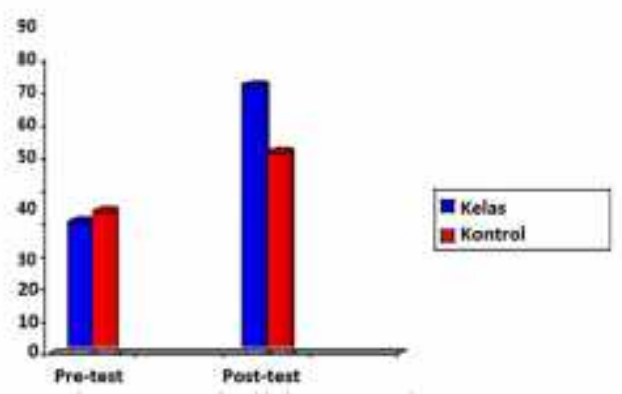

Gambar 1. Rata-rata hasil belajar pre-test dan post-test

Berdasarkan tabel diatas, menunjukan bahwa nilai rata-rata post-test untuk kelas eksperimen sebesar 82,20 dengan simpangan baku sebesar 9,04. Sedangkan nilai rata-rata post-test untuk kelas kontrol dengan sebesar 61,81 dengan simpangan baku sebesar 11,69. Jika dilihat nilai rata-rata hasil post-test kelas eksperimen dan kelas kontrol terdapat perbedaan nilai sebesar 20,39. Hal ini menunjukkan bahwa kelas yang diterapkan dengan model pembelajaran Pair Checks hasilnya lebih tinggi dari kelas yang diterapkan metode ceramah dan tanya jawab. Dari hasil yang di dapat membuktikan bahwa model pembelajaran Pair Checks efektif dalam meningkatkan hasil belajar siswa.

Adanya peningkatan hasil belajar menunjukan bahwa Pembelajaran dengan menggunakan model pembelajaran Pair Checks dapat melatih siswa untuk mempresentasikan kepada teman sekelas apa yang telah mereka kerjakan. Siswa memperoleh informasi maupun pengetahuan serta pemahaman yang berasal dari sesama teman dan guru. Hal ini sejalan dengan penelitian yang relevan Ridwan [3], yang menyimpulkan bahwa dengan penerapan model pembelajaran kooperatif Pair Checks dapat meningkatkan sikap ilmiah dan hasil belajar biologi siswa.

Model pembelajaran pair check memiliki kelebihan tersendiri yaitu meningkatkan kerja sama antar siswa, meningkatkan pemahaman atas konsep dan proses pembelajaran, serta melatih siswa berkomunikasi dengan baik dengan teman pasangannya [4]. Dalam pengajaran biologi menggunakan model pembelajaran Pair Checks memungkinkan siswa dapat bekerja sama dengan temannya di mana siswa saling bekerjasama dalam mempelajari materi yang dihadapi. Dari sini siswa memperoleh informasi maupun pengetahuan serta pemahaman yang berasal dari sesama teman dan guru. Perbedaan hasil belajar yang muncul juga disebabkan karena siswa yang diberi pembelajaran menggunakan model pembelajaran Pair Checks mempunyai pengalaman dalam mempresentasikan pendapatnya kepada teman.

\section{SIMPULAN}


Jurnal Biologi dan Pembelajarannya, Vol 6 No 2, Oktober 2019. Pp: 4-6

e-ISSN: $2406-8659$

Berdasarkan hasil penelitian dan pembahasan dapat disimpulkan bahwa model pembelajaran Pair Checks memiliki keefektifitasan dalam meningkatkan hasil belajar biologi siswa kelas VIII SMP Negeri 6 Lubuklinggau.

SARAN

\section{UCAPAN TERIMA KASIH}

\section{DAFTAR PUSTAKA}

[1] Supriyatna. 2006. Pembelajaran Taksonomi Blom. Jakarta: Prestasi Pustaka

[2] Suprijono. 2009. Statistika Untuk Penelitian. Bandung: Alfabeta. 2012. Metode Penelitian Pendidikan, Pendekatan Kualitatif, Kuantitatif, $R$ \& D. Bandung: Alfabeta.

[3] Ridwan. 2008. Metode Evaluasi Pendidikan. Jakarta: Penerbit Rineka Cipta

[4] Huda.2013. Model Pembelajaran Kooperatif. Bandung: Bumi Aksara 